\title{
PENINGKATAN KUALITAS PRODUK DAN PROSES KERJA PERAJIN BAMBU KARYA UTAMI DUSUN GUMAWANG, PUTAT, PATUK, GUNUNGKIDUL
}

\author{
Oleh: \\ Choirul Bariyah dan Wandhansari Sekar Jatiningrum \\ Teknik Industri, Universitas Ahmad Dahlan Yogyakarta \\ Email: choirul.bariyah@ie.uad.ac.id, \\ Email: wandhansari.sekar@ie.uad.ac.id
}

\section{Ringkasan}

Dusun Gumawang memiliki sumberdaya alam berupa tanaman bambu yang melimpah. Selama ini Warga Gumawang memanfaatkannya untuk keperluan hidup dengan menjual bamboo mentah (belum diolah) dengan harga yang murah. Sebagai upanya untuk meningkatkan nilai jual bamboo di gumawang, warga yang tergabung dalam kelompok perajin bamboo Karya Utami mencoba mengolagnya menjadi kipas dan besek. Namun demikian hasil olahan terbebut masih kurang dari sisi kualitas dan kuantitas iratannya. Sementara itu jumlah permintaan besek yang masuk selalu ada dan dengan jumlah yang relative besar, sehingga perajin Karya Utami kewalahan untuk memenuhinya dan melepas sejumlah pesanan yang masuk. Program pengabdian masyarakat yang dilakukan mencoba memberikan pendampingan dari sisi kualitas produk dan kualitas proseskerja dengan memberikan penyuluhan mengenai pentingnya kualitas dalam pemasaran produk. Sementara untuk mengupayakan terpenuhinya jumlah iratan bambu pendampingan yang dilakukan adalah dengan merancang alat irat bamboo untuk perajin bamboo Karya Utami, melakukan pelatihan dan evaluasi penggunaan mesin. Sejumlah program yang telah dilaksanakan mampu membuka wacana perajin akan tingginya peran kualitas produk untuk mendukung keberhasilan pemasaran. Perajin bamboo juga mendapatkan bekal mengenai pengeturan stasiun kerja yang ergonomis untuk mencapai kenyamanan dan keselamatan saat bekerja. Adapun hasil iratanbambu dengan mesin irat hasil perancangan jika dilihat dari standar ketipisan hasil iratan telah mampu memberikan hasil yang lebih tipis dari iratan manual, namun demikian masih ada perbaikan yang perlu dilakukan berkaitan dengan masih sering rusaknya bagian ujung hasil iratan bamboo yang dihasilkan oleh mesin, sehingga mesin masih perlu terus dievaluasi dan ditingkatkan performansinya.

Kata kunci : Bambu, Kualitas, Proses.

\begin{abstract}
Hamlet Gumawang has natural resources in the form of bamboo plants are abundant. So far Gumawang residents use it for the necessities of life by selling raw bamboo (untapped) at a cheap price. As upanya to increase the sale value of bamboo in gumawang, residents who are members of the bamboo craftsman Work Utami try mengolagnya become fan and besek. However, the processed products are still less than the quality and quantity of iratannya. Meanwhile, the number of requests entered by the incoming bulk is always there and with a relatively large amount, so the craftsman Utami is overwhelmed to fulfill it and release a number of incoming orders. Community service programs conducted try to provide assistance in terms of product quality and quality of work process by giving counseling about the importance of quality in product marketing. Meanwhile, to seek the fulfillment of the number of bamboo irrigation that is done by designing bamboo iris tool for bamboo craftsman Karya Utami, conducting training and evaluation of machine usage. A number of programs that have been implemented are able to open the artisans discourse will the high role of product quality to support the success of marketing. Bamboo craftsmen also get supplies on the ergonomic work station setting to achieve comfort and safety while working. The iratanbambu result with irat engine result of design if seen from standard of thinness of result of iratan have been able to give result which is thinner than manual irrigation, however there is still improvement which
\end{abstract}


need to be done related to still often damage the end of result of bamboo irrigation produced by machine, so machines still need to be continuously evaluated and improved performance.

Keywords: Bamboo, Quality, Process.

\section{A. PENDAhULUAN}

Dusun Gumawang, Patuk Gunung Kidul merupakan dusun yang sangat produktif. Banyak macam usaha rumahan yang dijalankan oleh warga dusun tersebut mulai dari pengolahan coklat, produksi berbagai macam keripik, kerajinan kayu, serta pengolahan bambu. Paguyuban perajin bambu Karya Utami merupakan satu usaha masyarakat dusun Gumawang yang memafaatkan sumber daya alam berupa tanaman bambu yang sangat melimpah.

Selama ini warga hanya menjual bambu mentah (belum diolah) dengan harga yang relatif murah kepada perajin bamboo di luar Gumawang. Kelompok perajin Karya Utami berusaha meningkatkakan nilai jual bambu dengan memproduksi kipas dan besek. Kipas hasil produksi Karya Utami masih belum memiliki pasar yang potensial. Pasar yang dibidik adalah untuk keperluan sebagai cindera mata. Pada perkembangannya permintaan atas produk besek meningkat pesat baik kuantitas pesanan yang masuk maupun variansi jenis bentuk besek. Tingginya jumlah pesanan yang masuk tidak mampu dipenuhi oleh pengrajin. Kendala yang dihadapi adalah kecepatan irat bambu dan kualitas hasil iratan warga dusun gumawang masih jauh dari yang dibutuhkan untuk dapat memenuhi permintaan yang ada. Kondisi tersebut membawa dampak pada hilangnya sejumlah pesanan yang seharusnya dapat mendatangkan income bagi perajin. Disamping kecepatan irat yang belum mampu memenuhi jumlah pesanan, proses irat bambu yang dilakukan masih sangat berpotensi untuk terjadinya kecelakaan kerja seperti tersayat pisau ataupun bilah bambu, mengingat proses ini dilakukan secara manual tanpa ada fasilitas pengaman. Dalam proses irat bamboo posisi kerja operator pada saat ini sangat berpotensi menimbulkan keluhan Moskuloskeletal Disorder (MSDs) yaitu keluhan-keluhan kelelahan pada sistem otot pada tubuh pekerja yang pada kelanjutannya dapat menimbulkan cedera permanen. Ilustrasi kondisi kerja perajin saat melakukan pengiratan bamboo dapat dilihat pada gambar 1.

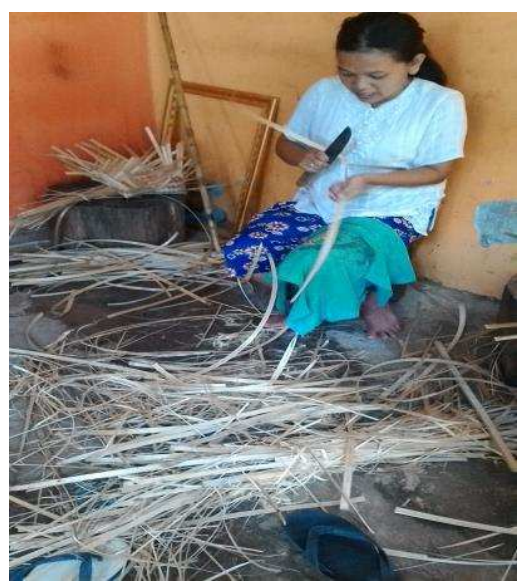

Gambar 1. Proses Irat Bambu 
Diterbitkan oleh Lembaga Pengabdian kepada Masyarakat

Universitas Ahmad Dahlan Yogyakarta

Berdasarkan permasalahan yang ada program pengabdian masyarakat yang dilakukan mencoba melakukan pendampingan dari sisi menanamkan pemahaman akan pentingnya kualitas, implementasi ergonomi dan keselamatan kerja, serta pembuatan fasilitas kerja untuk mengupayakan produksi iratan bambu yang lebih aman dan lebih produktif. Adapun tujuan yang ingin dicapai dari kegiatan pengabdian selama kurang lebih tiga bulan ini adalah usaha industri kecil kerajinan bambu yang dimiliki masyarakat Dusun Gumawang mampu memproduksi kerajinan bambu yang berkualitas dan memiliki daya saing sehingga dapat berkontribusi untuk meningkatkan perekonomian masyarakat.

\section{B. METODE}

Program pengabdian masyarakat yang dilakukan selama kurang lebih 3 bulan dari bulan Mei -Agustus 2017 ini menggunakan beberapa metode pendampingan sebagai berikut:

1. Penyuluhan

Penyuluhan dilakukan untuk mensosialisasikan 3 hal berikut:

a. Pentingnya kualitas produk untuk keberhasilan pemasaran.

b. Pentingnya penerapan ergonomi dan keselamatan kerja bagi Usaha Kecil Menengah

2. Pengenalan Teknologi/Perancangan Alat

Salah satu jenis pendampingan yang dilakukan adalah dengan merancang mesin irat bambu dengan harapan dapat meningkatkan jumlah produksi serta meningkatkan keamanan dan kenyamanan kerja perajin bamboo dusun Gumawang.

3. Pelatihan

Pelatihan yang dilakukan dalam program pendampingan perajin bambu berupa pelatihan mekanisme penggunaan mesin irat hasil rancangan. Pelatihan dilakukan di laboratorium Jurusan Teknik Mesin Universitas Muhammadiyah Yogyakarta. Dalam pelatihan ini juga sekaligus dilakukan evaluasi hasil iratan bambu dengan mesin irat.

\section{HASIL}

Rangkaian aktifitas pengabdiam masyarakat yang telah dilakukan dapat memberikan bekal pemahaman pada anggota kelompok perajin bamboo dusun Gumawang. Sesuai dengan rencana yang telah disusun pada awal perencanaan program, berikut adalah hasil pelaksanaan setiap aktifitas yang dijalankan:

1. Pelatihan Pentingnya kualitas produk untuk keberhasilan pemasaran mampu memberikan sosialisasi arti penting kualitas pada produk yang dibuat dan dipasarkan. Perajin bambu yang pada awalnya masih belum mementingkan kualitas produk yang dibuat pada akhirnya menyadari bahwa agar produknya dapat bersaing di pasar maka harus senantiasa memperhatikan usaha pencapaian kualitas yang tinggi pada produk yang yang dihasilkan. Gambar 2. menunjukkan kegiatan 
penyuluhan yang dilakukan pada tanggal 12 Mei 2017 dengan tema pentingnya kualitas produk pada pemasaran.

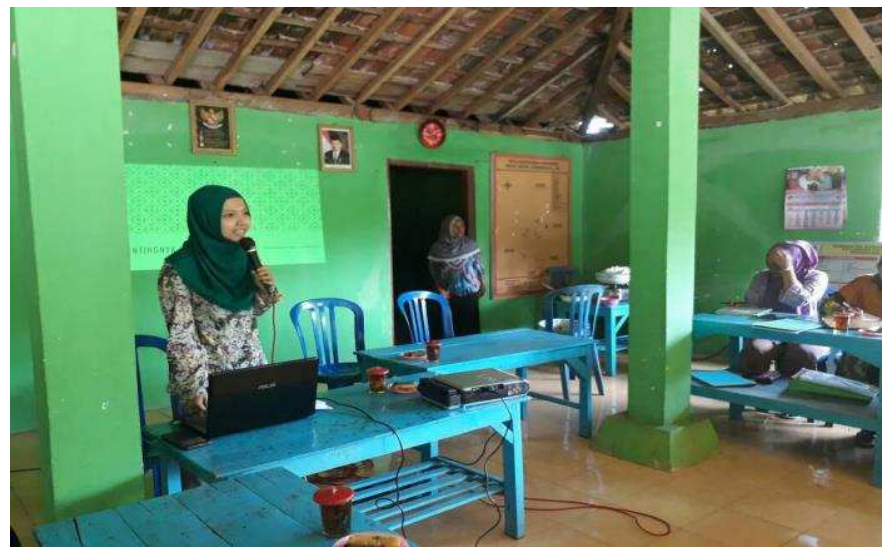

Gambar 2. Pelaksanaan Penyuluhan Pentingnya Kualitas dalam Pemasaran

2. Peyuluhan implementasi ergonomi dan keselamatan kerja pada Usaha Kecil Menengah, mampu membuka wawasan dan pemahaman perajin bambu bahwa proses kerja yang sederhana pun perlu direncanakan dengan baik dalam pegaturan tempat kerjanya. Hal ini untuk menghindari cidera maupun kecelakaan kerja yang akan sangat merugikan baik dari sisi kesehatan kerja maupun finansial. Gambar 3 menunjukkan kegiatan penyuluhan penerapan ergonomi dan keselamatan kerja yang dilaksanakan 12 Mei 2017 di dusun Gumawang.

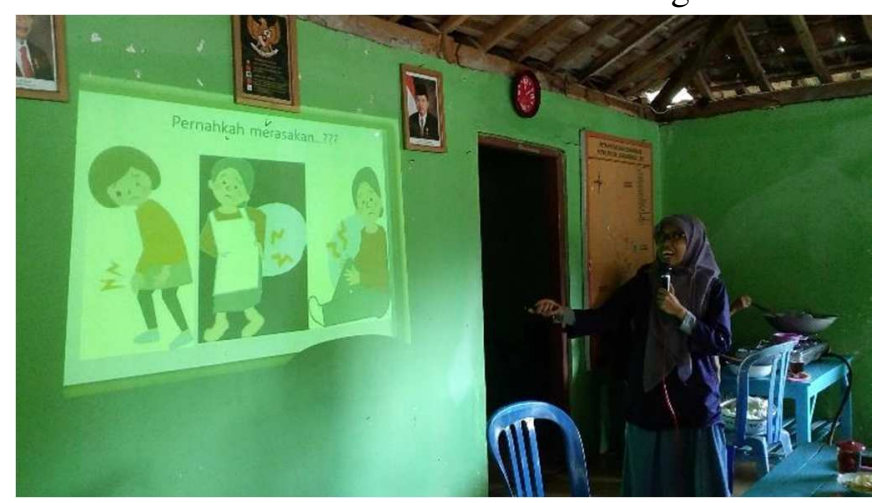

Gambar 3. Penyuluhan Penerapan ergonomi dan keselamatan kerja

3. Perancangan Mesin Irat Bambu

Perancangan mesin irat bambu dilakukan dengan bekerjasama dengan Jurusan Teknik Mesin Universitas Muhammadiyah Yogyakarta (UMY). Spesifikasi mesin, mekanisme kerja serta pemilihan komponen ditentukan dengan melibatkan pihak perajin bambu, pengusung program pengabdian masyarakat dan pihak lab teknik mesin UMY. Gambar 4. Menunjukkan mesin irat hasil rancangan. 
Diterbitkan oleh Lembaga Pengabdian kepada Masyarakat

Universitas Ahmad Dahlan Yogyakarta

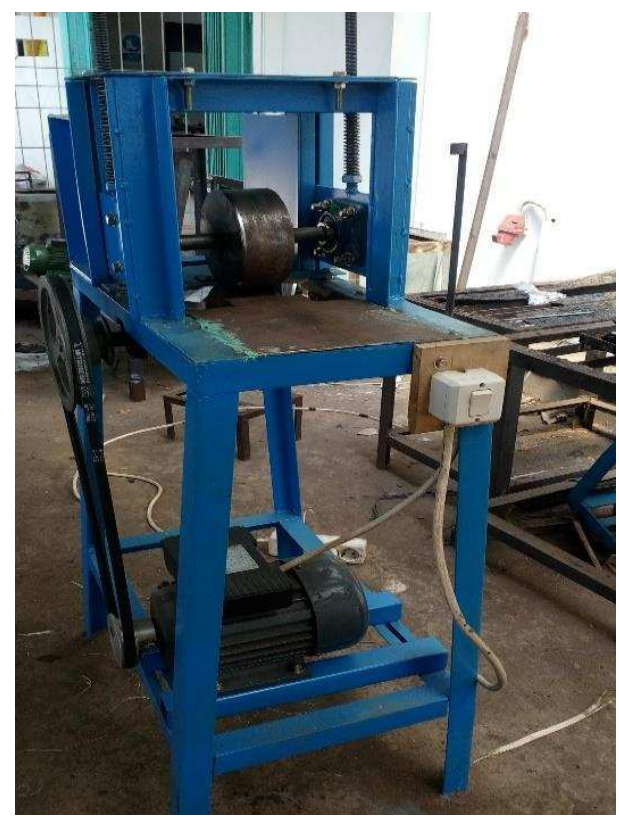

Gambar 4. Mesin Irat Hasil Rancangan

4. Penjelasan dan pelatihan penggunaan mesin

Penjelasan spesifikasi dan mekanisme penggunaan mesin irat dilakukan di Laboratorium Jurusan Teknik Mesin UMY dengan penjelasan diberikan langsung oleh perancang desain mesin irat bambu yaitu Bapak Totok Suwanda, S.T., M.T. Gambar 5 menunjukkan aktivitas penjelasan penggunaan mesin irat bambu dan gambar 6 memberikan informasi saat perajin bambu gumawang mencoba menggunakan mesin hasil rancangan.

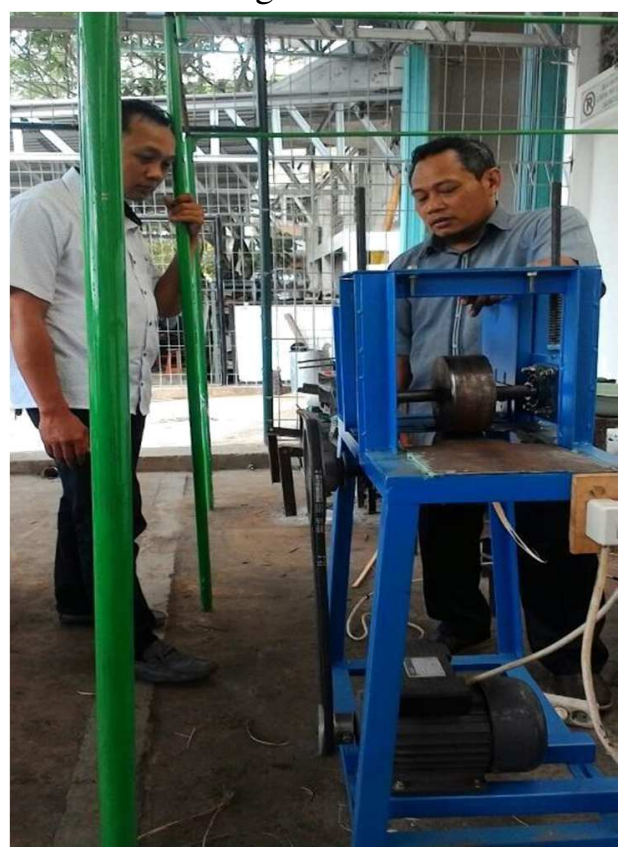

Gambar 5. Penjelasan penggunaan mesin oleh perancang 


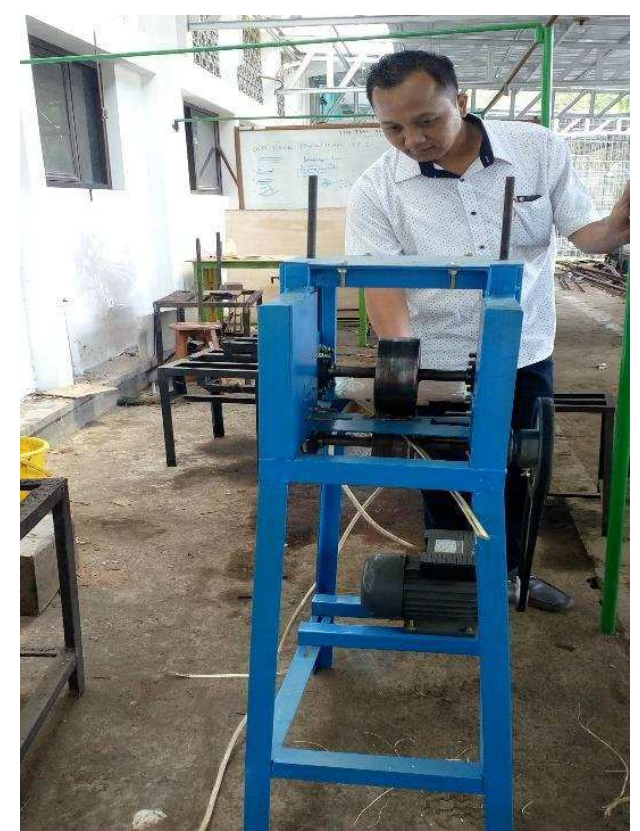

Gambar 6. Pelatihan penggunaan mesin irat bambu hasil rancangan

5. Evaluasi hasil irat bambu dengan mesin hasil rancangan.

Setelah dilakukan pelatihan dan ujicoba mesin irat yang telah dirancang selanjutnya dilakukan evaluasi atas hasil iratan bambu yang didapatkan. Berdasarkan hasil evaluasi yang melibatkan pengusung PPM, pihak perajin dan perancang mesin, diperoleh gambaran bahwa dari sisi kecepatan, mesin irat yang telah dirancang mampu menunjukkan kinerja yang baik dimana mesin irat bamboo mampu menghasilkan jumlah iratan bambu dengan waktu yang lebih singkat dibandingkan dengan iratan bambu yang dihasilkan dari proses manual. Standar ketebalan mesin irat bambu yang diinginkan juga sudah mampu dicapai, namun bagian ujung atas atau bawah pada iratan bambu masih terlihat pecah. Gambar 7 memberikan informasi visual perbandingan hasil irat bambu secara manual dan dengan mesin hasil rancangan.
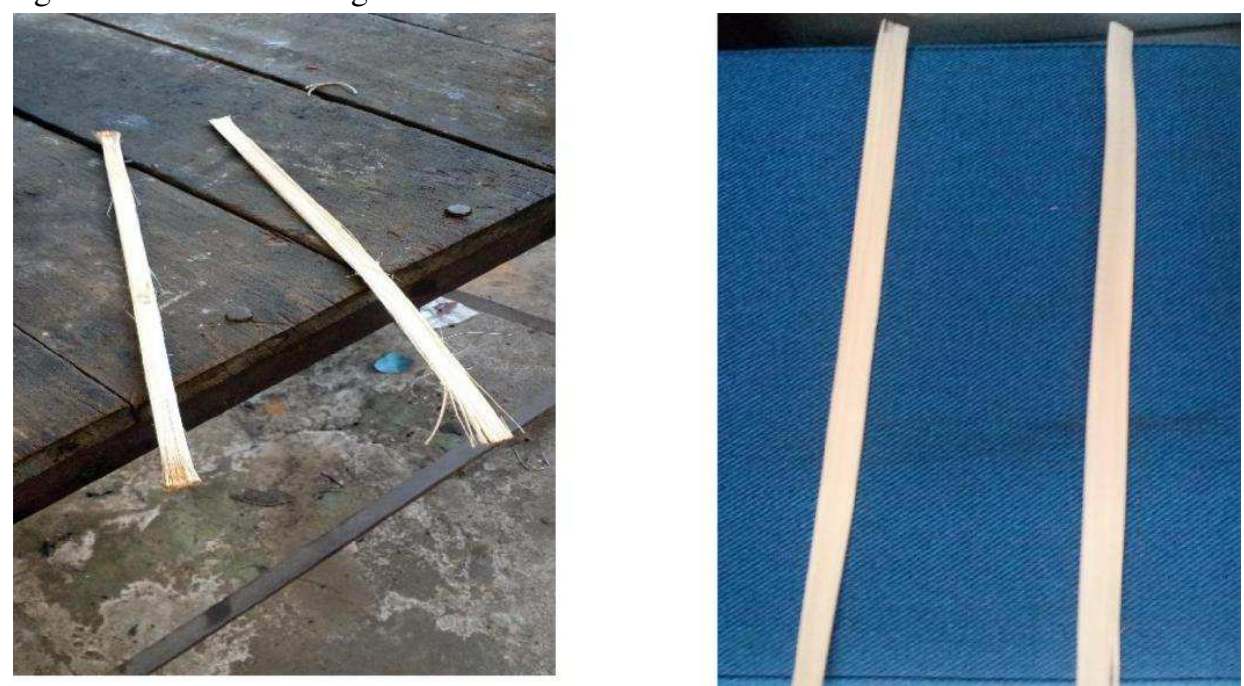

Gambar 7. Perbandingan hasil irat bambu dengan mesin irat dan pisau manual 
Diterbitkan oleh Lembaga Pengabdian kepada Masyarakat

Universitas Ahmad Dahlan Yogyakarta

\section{KESIMPULAN}

Pelaksanaan program Pendampingan perajin bambu Karya Utami di dusun Gumawang dapat memberikan kontribusi sebagai berikut:

1. Memberikan bekal pemahaman pada perajin bambu akan pentingnya kualitas produk dalam pemasaran serta pentingnya implementasi ergonomi dan keselamatan kerja dalam menjalankan usaha kerajinan bambu.

2. Mesin irat yang dirancang mampu menghasilkan jumlah iratan yang lebih banyak dibanding irat manual. Namun demikian mesin belum mampu menghasilkan iratan yang halus selayaknya irat manual. Hasil iratan mesin tampak pecah di bagian ujung bilah bambu.

3. Perlu dilakukan pengembangan secara kontinyu untuk mendapatkan rancangan mesin irat yang mampu memenuhi standar ketipisan dan kehalusan yang dibutuhkan pada proses pembuatan besek. 
